DOI: https://doi.org/10.24127/ajpm.v10i4.3971

\title{
KEMAMPUAN REPRESENTASI: IMPLEMENTASI PENGEMBANGAN DESAIN DIDAKTIS PADA PEMBELAJARAN MATEMATIKA DI SEKOLAH MENENGAH ATAS
}

\author{
Elsa Komala $^{1^{*}}$, Didi Suryadi ${ }^{2}$, Dadan Dasari $^{3}$ \\ ${ }^{1 *, 2,3}$ Sekolah Pascasarjana, Universitas Pendidikan Indonesia, Bandung, Indonesia \\ ${ }^{1 *}$ Universitas Suryakancana, Cianjur, Indonesia \\ *Corresponding author. \\ E-mail: $\quad$ elsakomala@gmail.com ${ }^{1 *}$ \\ $\underline{\text { ddsuryadi1@gmail.com }}^{2)}$ \\ dadan.dasari@upi.edu ${ }^{3}$ )
}

Received 12 July 2021; Received in revised form 23 November 2021; Accepted 15 December 2021

\begin{abstract}
Abstrak
Kemampuan representasi matematis merupakan salah satu tujuan pembelajaran matematika di sekolah yang digunakan sebagai alat bantu untuk menemukan solusi dari masalah matematika, akan tetapi siswa masih kesulitan dalam melakukan kemampuan representasi matematis dan minim kemampuan representasi yang baik. Tujuan dari penelitian ini adalah untuk menganalisis hasil implementasi dari desain didaktis hasil pengembangan untuk meminimalisir learning obstacle yang terjadi terkait kemampuan representasi pada pembelajaran matematika. Penelitian ini menggunakan metode kualitatif dengan studi fenomenologi dan pengembangan dengan Didactical Design Research (DDR). Subjek terdiri dari 38 siswa kelas X beserta 3 orang guru matematika. Soal tes kemampuan representasi dan studi dokumentasi digunakan pada saat implementasi desain didaktis. Hasil dari penelitian menunjukan bahwa berdasarkan learning obstacle yang terjadi terkait kemampuan representasi siswa yang diperoleh selanjutnya dibuat dan dikembangkan desain didaktis berdasarkan learning obstacle yang telah teridentifikasi sebagai pendahuluan kemudian diimplementasikan, sehingga pelaksanaan pembelajaran matematika dengan menggunakan desain didaktis terlaksana dengan baik akibatnya kemampuan representasi matematis siswa dapat diminimalisir kesalahannya terutama pada proses membuat pemodelan matematika, selain itu proses visual dan pembuatan kata-kata tertulis.
\end{abstract}

Kata kunci: Desain didaktis; kemampuan representasi.

\begin{abstract}
Mathematical representation ability is one of the objectives of learning mathematics in schools which is used as a tool to find solutions to mathematical problems, but students still have difficulty in performing mathematical representation skills and lack good representation skills. The purpose of this study is to analyze the results of the implementation of the didactic design as a result of the development to minimize learning obstacles that occur related to representational abilities in mathematics learning. This research uses qualitative methods with phenomenological studies and development with Didactical Design Research (DDR). The subjects consisted of 38 students of class X and 3 mathematics teachers. Representational ability test questions and documentation studies are used during the implementation of the didactic design. The results of the study show that based on the learning obstacle that occurs related to the student's representation ability obtained, then a didactic design is made and developed based on the learning obstacle that has been identified as an introduction and then implemented, so that the implementation of mathematics learning by using a didactic design is carried out properly as a result, students' mathematical representation abilities can be achieved. errors are minimized, especially in the process of making mathematical modeling, in addition to the visual process and the creation of written words.
\end{abstract}

Keywords: Didactic design; representation ability.

This is an open access article under the Creative Commons Attribution 4.0 International License 
DOI: https://doi.org/10.24127/ajpm.v10i4.3971

\section{PENDAHULUAN}

Bagian penting dari belajar matematika adalah belajar menggunakan bahasa, konvensi, dan representasi matematika (NCTM, 2000). Dalam belajar matematika, representasi merupakan dasar atau landasan bagaimana seorang siswa dapat memahami dan menggunakan ide-ide matematika (Dahlan \& Juandi, 2011). Sedangkan kemampuan representasi merupakan bentuk interpretasi pemikiran siswa terhadap suatu masalah, yang digunakan sebagai alat bantu untuk menemukan solusi dari masalah matematika dapat berupa katakata tertulis atau verbal, visual berupa gambar, tabel, grafik dan ekspresi atau simbol matematika.

Representasi matematika juga memiliki peran penting dalam pembelajaran matematika, dengan alasan epistemologi yang kuat yaitu matematika memainkan bagian yang esensial dalam mengkonseptualisasikan dunia nyata dan matematika memberikan kegunaan yang sangat luas dari homomorfisma dimana reduksi struktur satu sama lain merupakan hal yang esensial (Goldin, 2002). Salah satu bagian dari upaya yang dapat dilakukan siswa adalah dengan membuat representasi dari permasalahan yang disajikan. Model atau representasi yang dibuat bisa bermacam-macam tergantung pada kemampuan masingmasing individu dalam menginterpretasikan masalah yang ada. Konsep matematika apapun harus direpresentasikan dengan cara-cara tertentu jika ingin hadir dalam pemikiran siswa (Cadez, 2018).

Dalam pembelajaran matematika tingkat SMA semua permasalahan dan materi yang disajikan sudah mengaitkan materi serta soal-soal dengan masalah nyata. Permasalahan yang masih terjadi pada siswa berkaitan dengan belum mampunya menyajikan masalah yang diberikan oleh guru ke dalam bentuk yang berbeda, artinya siswa hanya mampu memahaminya saja tetapi belum bisa mengaplikasikan pengetahuan yang mereka miliki secara maksimal kedalam bentuk lain serta memperjelas masalah yang terkait dengan konteks kehidupan sehari-hari. Kurang penguasaan materi prasyarat juga menjadi salah satu faktor minimnya kemampuan representasi. Menurut Khasanah (2015) bahwa kecenderungan kesalahan siswa dalam menyelesaikan soal terjadi pada aspek prasyarat, dimana siswa kurang mampu dalam mentransformasikan kalimat kedalam model matematika.

proses pengkonsepsian, penciptaan kondisi alur belajar dan pemaknaan suatu objek matematis tidak hanya terjadi pada konteks pembelajaran, melainkan juga melalui sumber belajar yakni buku atau bahan tertulis. Dengan demikian, bagi seorang guru selain perlu menguasai konten yang akan diajarkan perlu juga mempunyai pengetahuan terkait siswa dan mampu menciptakan situasi didaktis sehingga proses belajar akan terdorong secara optimal dan dapat menarik minat siswa dalam kegiatan belajar mengajar (Mulyana et al., 2014). Sehingga salah satu peran guru harus memberikan kesempatan belajar siswa pada saat pembelajaran matematika. Sejalan dengan Amiripour et al., (2012) guru matematika mempunyai tanggung jawab secara langsung membentuk kesempatan belajar siswa,

Dalam hal ini siswa belum bisa memprediksi fenomena yang diberikan guru untuk ditafsirkan, memahami informasi yang diberikan, sehingga konsep siswa yang dimiliki sebelumnya seolah-olah tidak bisa digunakan dan dimaksimalkan untuk memperjelas 
permasalahan saat pengerjaan soal. Pembelajaran matematika di kelas hendaknya memberikan kesempatan yang cukup bagi siswa untuk dapat melatih dan mengembangkan kemampuan representasi matematis sebagai bagian yang penting dalam menyelesaikan masalah. Masalah yang disajikan disesuaikan dengan isi dan kedalaman materi pada jenjang masingmasing dengan memperhatikan pengetahuan awal atau prasyarat dan kebiasaan berpikir yang dimiliki siswa.

Selain siswa, makna dan pemaknaan tentang suatu situasi dan alur belajar berkaitan juga dengan pendidiknya, guru juga harus dapat merancang desain pembelajaran yang dapat mengembangkan potensi yang dimiliki siswa dan sesuai dengan kecenderungan karakteristik siswa. Merancang desain pembelajaran tidaklah mudah, karena pembelajaran merupakan skenario atau gambaran yang harus dilalui guru dalam menyampaikan materi kepada siswa. Sejalan dengan (Yunarti, 2014) Rancangan Pelaksanaan Pembelajaran (RPP) yang disusun guru hanya memperhatikan interaksi antara guru dengan siswa dan antar siswa saja, sedangkan interaksi siswa dengan materi cenderung diabaikan. Hal ini mengakibatkan pembelajaran kurang efektif, akibatnya guru harus mengulang kembali konsep yang telah dijelaskan. Oleh karena itu desain pembelajaran yang digunakan harus berdasarkan hambatan belajar siswa dan kecenderungan karakteristik siswa.

Berdasarkan penelitian yang telah dilaksanakan oleh Yusnita et al. (2016), Arnidha (2016), Kholiqowati et al. (2016), Rezeki (2017), Putra (2018), Wilujeng (2019), kesemuanya penelitian yang dilakukan kebanyakan menggunakan model pembelajaran untuk mengembangkan representasi matematis siswa, tanpa adanya bantuan desain didaktis yang disesuaikan dengan kebutuhan berdasarkan learning obstacles siswa serta tidak memperhatikan interaksi antara siswa dengan sumber belajar yang digunakan.

Salah satu usaha yang dapat dilakukan guru adalah dengan menyiapkan desain pembelajaran matematika dengan baik, yakni dengan membuat perencanaan pembelajaran yang lebih rinci dan dirancang dengan strategi alternatif untuk mengantisipasi permasalahan siswa dan berbagai kemungkinan respon siswa selama proses pembelajaran atau keragaman lintasan belajar. Sehingga dalam penelitian ini mengimplementasikan hasil Didactical Design Research (DDR) yang merupakan suatu desain untuk membantu seseorang dalam membuat konsep dan memfasilitasi proses belajar dan menyajikan secara komprehensif tentang apa yang disajikan, bagaimana kemungkinan tanggapan siswa, dan bagaimana mengantisipasinya. Selain itu, desain didaktis merupakan rancangan untuk membantu siswa dalam hal pengkonsepsian dan pengkondisian untuk memfasilitasi serta membantu terjadinya proses belajar mengajar dalam pengetahuan matematika tertentu.

Berdasarkan uraian yang telah dijelaskan, tujuan dari penelitian ini adalah untuk menganalisis hasil implementasi dari desain didaktis hasil pengembangan untuk meminimalisir learning obstacle yang terjadi terkait kemampuan representasi matematis siswa di Sekolah Menengah Atas.

\section{METODE PENELITIAN}

Metode yang digunakan adalah penelitian kualitatif, dengan studi fenomenologi. Pengembangan desain 
didaktis berdasarkan learning obstacle yang telah teridentifikasi dilakukan pada saat studi pendahuluan pada materi trigonometri kelas X pada siswa SMA. Adapun hasil Identifikasi learning obstacle yang terjadi yang dijadikan rujukan dan dasar dalam membuat desain didaktis berdasarkan hasil penelitian yang dilakukan Komala et al., (2020), yakni Ontogenic obstacle psikologis yang teridentifikasi berkaiatan dengan minat dan motivasi siswa terhadap pembelajaran pada konsep trigonometri, ontogenic obstacle konseptual berkaitan dengan konseptual desain yang terlalu sulit dan dan terlalu cepat bagi siswa; Didactical obstacle berkaitan dengan desain yang kurang merepresentasikan keterkaitan antar konsep sehingga tidak selaras dengan kebutuhan kesinambungan berpikir siswa (kemampuan representasi matematik); Epistemological obstacle berkaitan dengan pengetahuan siswa dalam menyelesaikan masalah kemampuan representasi berkaitan dengan konsep trigonometri, sebagai berikut: (1) hambatan epistimologis terkait concept image yang telah ada mengenai definisi dan jenis segitiga sebagai prasyarat materi trigonometri, (2) hambatan epistimologis terkait dengan konteks variasi informasi yang tersedia pada soal, (3) hambatan epistimologis terkait dengan kemampuan siswa dalam merepresentasikan visual, merepresentasikan dalam bentuk pemodelan matematika dan merepresentasikan dalam bentuk katakata. Setelah itu didapatkan pengebangan perangkat pembelajaran berupa desain didaktis untuk 8 pertemuan pembelajaran pada materi trigonometri dan bahan ajar berupa lembar kerja siswa untuk setiap pertemuan beradasarkan tahapan Didactical Design Research (DDR).
Subjek dalam penelitian ini adalah 38 siswa kelas $\mathrm{X}$ beserta 3 orang guru matematika. Soal tes kemampuan representasi, studi dokumentasi digunakan pada saat implementasi desain didaktis.

Tes digunakan untuk mendeskripsikan kemampuan representasi siswa yang terjadi setelah implementasi desain didaktis dalam bentuk soal uraian sebanyak 6 soal, dimana memperhatikan tiga keterampilan representasi untuk memecahkan masalah matematika.

Keterampilan representasi yang dirujuk secara bersamaan dikembangkan dan digunakan sebagai indikator dalam penelitian ini untuk melihat proses representasi matematis siswa menurut (Milrad, 2002), a) Keterampilan representasi bahasa: keterampilan untuk menerjemahkan sifat dan hubungan yang diamati dalam masalah matematika ke dalam representasi verbal kata-kata tertulis; b) Keterampilan representasi gambar atau grafik; dan c) Keterampilan representasi simbol aritmatika.

Studi dokumentasi yang digunakan adalah catatan lapangan mengenai pelaksanaan pembelajaran menggunakan desain didaktis yang dibantu oleh guru matematika yang kemudian dilakukan Forum Group Discussion mengenai kekurangan yang terjadi.

Setelah implementasi desain didaktis, analisis data dilakukan dengan membandingkan hasil dokumentasi selama implementasi dengan rancangan desain didaktis hasil pengembangan untuk melihat realitas situasi didaktis dan alur belajar yang terjadi. Sedangkan hasil jawaban tes siswa dibuat kode berupa kata-kata atau frasa yang digunakan untuk mengidentifikasi, mendeskripsikan yang kemudian 
DOI: https://doi.org/10.24127/ajpm.v10i4.3971

diklasifikasikan berdasarkan indikator kemampuan representasi. Kemudian kedua data tersebut dianalisis secara naratif dan dideskripsikan sesuai dengan kenyataan dilapangan secara mendalam berdasarkan fenomena yang terjadi. Adapun alur dan prosedur yang digunakan dalam penelitian ini disajikan pada Gambar 1.

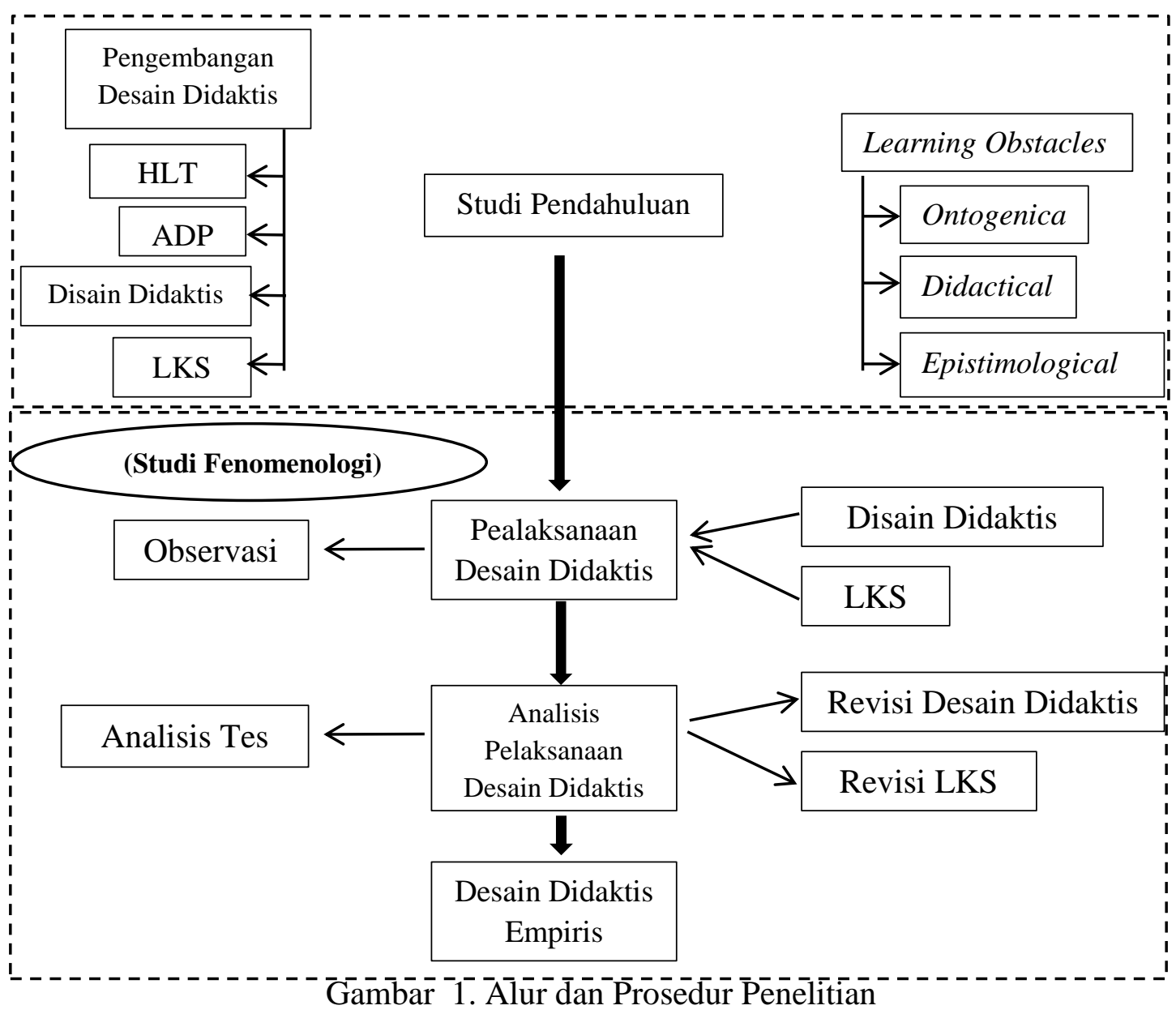

HASIL DAN PEMBAHASAN

Bentuk desain didaktis yang dikembangkan didasarkan pada learning obstacle yang terjadi pada siswa, sesuai dengan kebutuhan siswa, dan analisis teori yang dilakukan, yang kesemuanya itu telah diperoleh hasil dari hasil analisis pendahuluan yang dilakukan.

Langkah selanjutnya desain didaktis hasil pengembangan diimplementasikan di kelas selama 8 kali pertemuan berdasarkan pokok bahasan trigonometri mencakup ukuran sudut, perbandingan trigonometri pada segitiga siku-siku dan untuk sudut di kuadran, nilai-nilai sudut istimewa, sudut-sudut berelasi, identitas trigonometri, aturan sinus dan cosinus. Pada pertemuan ke sembilan merupakan pertemuan terakhir, dilaksanakan tes akhir untuk mengetahui kemampuan representasi matematis siswa setelah pembelajaran matematika dengan desain didaktis.

Kegiatan pembelajaran di kelas, didesain dengan menerapkan model yang sudah ada sebelumnya secara implisit untuk dimodifikasi dengan mengintegrasikan peer instruction, 
sehingga peran siswa serta kemampuan yang dimiliki siswa bisa berkembang dan siswa lebih aktif, hal ini bertujuan menghindari hambatan didaktis. Salah satu contoh kegiatan diskusi pada saat peer instruction disajikan pada Gambar. 2.

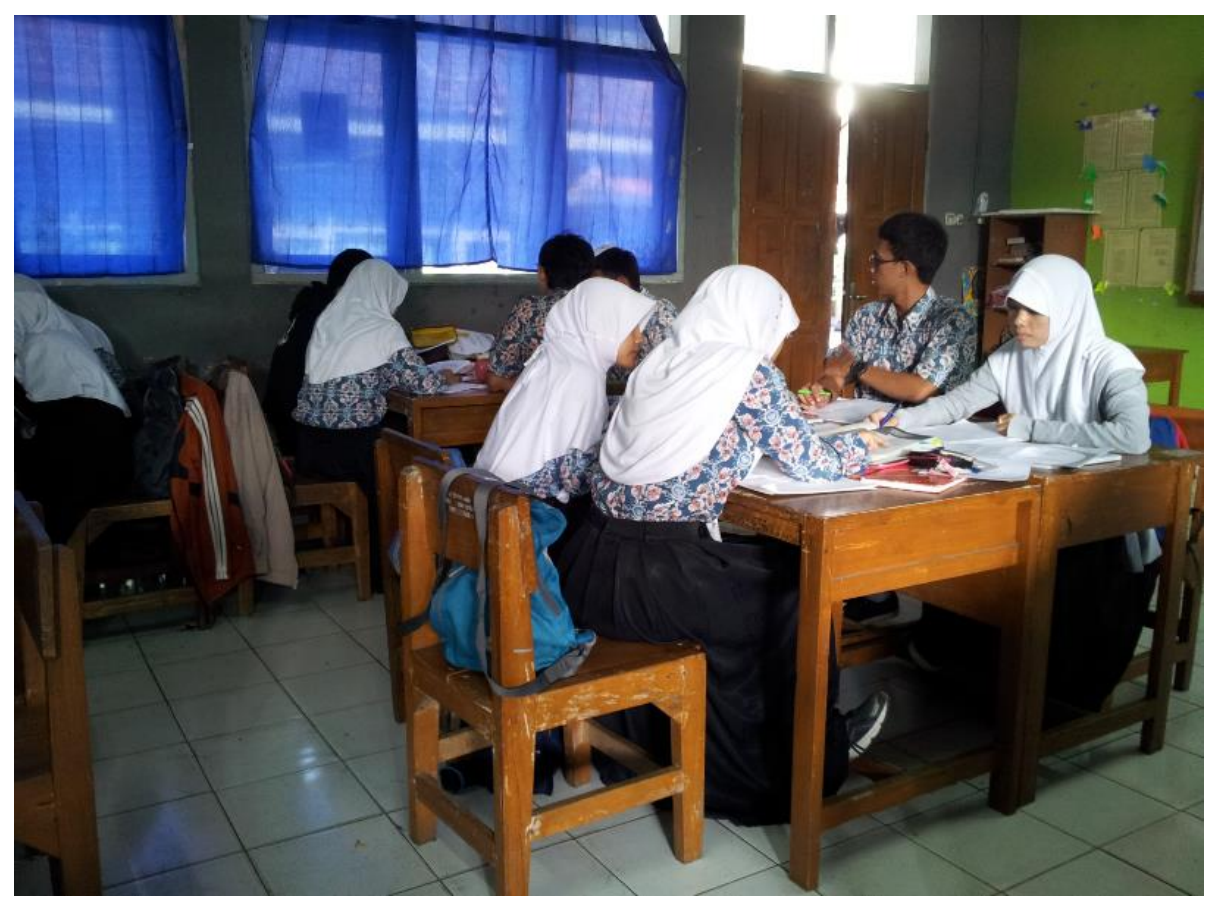

Gambar 2. Kegiatan Pembelajaran pada Kegiatan peer instruction

Pada pertemuan pertama disajikan penguatan materi prasyarat, agar siswa memiliki modal yang kuat mengenai materi sebagai dasar untuk mempelajari materi baru yang akan dibahas selanjutnya, hal ini untuk menghindari hambatan epistimologis

Hampir seluruh siswa dalam pelaksanaan desain didaktis, baik dari pertemuan pertama sampai pertemuan kedelapan melakukan proses representasi matematis dengan benar. Pada proses siswa membuat representasi visual dimana siswa membuat gambar untuk memperjelas suatu permasalahan sehingga memudahkan dalam menyelesaikan suatu permasalahan. Hal tersebut didukung pada proses pembelajaran dengan pembiasaan dalam pemberian konsep ditunjang dengan menggunakan gambar atau visual yang sudah disajikan ataupun dibuat oleh siswa itu sendiri, selain itu pemberian evaluasi di akhir pembelajaran dengan pemberian soal yang menuntut siswa untuk melakukan proses representasi visual dalam menyelesaikannya. Begitu juga pada proses siswa membuat model atau ekspresi matematik serta membuat kata-kata tertulis hamper seluruh siswa dapat melakukannya dengan baik walaupun tidak menutup kemungkinan siswa dibantu dengan pemberian scaffolding dengan memberikan pertanyaan.

Pada tahap evaluasi hasil kemampuan representasi matematis, pada proses siswa membuat model atau ekspresi matematis yang tersaji pada soal nomor 6, terdapat 29 orang siswa menyelesaikan soal secara benar, 8 orang siswa ada yang melakukan proses benar tetapi salah perhitungan diakhir jawaban, ada yang tidak tuntas 
menyelesaikan, ada yang menggunakan rumus benar tetapi hasil akhir masih keliru, adapun 1 siswa tidak menjawab soal tersebut, sehingga dapat dijelaskan bahwa hampir seluruh siswa sudah melakukannya dengan benar dilihat dari hasil jawaban tes akhir siswa menjawab dengan benar.

Pada proses siswa membuat katakata tertulis yang disajikan pada soal nomor 1 dan 4. Pada soal nomor 1 , terdapat 26 siswa yang menjawab benar sedangkan 12 orang siswa yang lain menjawab dengan memberikan alasan dan kata-kata yang salah, ada juga yang jawaban benar tetapi tidak menggunakan alasan atau kata-kata tertulis. Sedangkan pada soal nomor 4 hanya 7 siswa yang menjawab benar, 31 siswa yang lain ada yang benar menggunakan kata-kata pada kesimpulan tetapi pada proses perhitungan ada yang keliru dengan tidak dilengkapi gambar, perhitungan salah, bahkan ada yang membuat kesimpulan yang salah.

Pada proses representasi visual tersaji pada soal nomor 2, nomor 3 dan nomor 5. Pada soal no 2, proses representasi menggunakan gambar sudah ada tetapi masih keliru dalam mengilustrasikan gambar yang dimaksud, pada soal nomor 3 hanya 14 siswa menggunakan penyelesaian dengan gambar, sisanya tidak merepresentasikan soal yang disajikan ke bentuk gambar sehingga penyelesaiannya pun salah, bahkan ada 1 siswa yang tidak menjawab soal tersebut. Pada soal nomor 5, siswa yang menjawab benar ada 33 orang, 3 orang tidak menggambar dan 2 orang tidak menjawab soal tersebut.

Sehingga untuk proses representasi dengan menggunakan katakata dan representasi visual, sebagian siswa sudah benar akan tetapi masih terdapat beberapa siswa yang masih melakukan kesalahan dalam membuat gambar untuk memperjelas permasalahan yang diberikan, hal tersebut terjadi kemungkinan disebabkan faktor dari kemampuan siswa itu sendiri dengan kemampuan siswa yang heterogen, kesalah itu terjadi pada siswa yang kemampuan awal matematika nya kurang, berdasarkan konfirmasi dari siswa mereka cenderung lebih mudah menyelesaikan permasalahan dengan langsung membuat pemodelan matematik karena konsep atau rumus yang digunakannya dalam menyelesaikan permasalah tersebut hafal, selain itu mereka masih suka keliru dalam membuat segitiga di koordinat kartesius dan membuat gambar segitiga siku-siku dari permasalahan kontekstual.

Hasil dari implementasi desain didaktis pada pembelajaran matematika siswa dapat meminimalisir kesalahan yang terjadi terkait kemampuan representasi serta dapat membangun kemampuan representasi siswa, hal tersebut dikarenakan bahan ajar (LKS) yang diberikan tiap pertemuan dapat memudahkan siswa untuk memahami materi dan menambah minat siswa untuk belajar trigonometri juga berlatih secara mandiri. Hal tersebut sejalan dengan (Devesh \& Nasseri, 2014). Mengungkapkan bahwa pembelajaran matematika menggunakan modul efektif.

Kemampuan representasi efek dari implementasi desain didaktis tergambar dari hasil jawaban tes siswa, salah satunya pada proses membuat pemodelan matematis, dimana hampir semua siswa menjawab dengan benar. Hal tersebut mengindikasikan bahwa yang dapat berakibat besar dalam Ways of Understanding (WoU) siswa terhadap kemampuan representasi. 
DOI: https://doi.org/10.24127/ajpm.v10i4.3971

Cara penyelesaian soal dan pemahaman mengenai konsep siswa bisa lebih baik, dikarenakan siswa dapat memahami dan mengingat pola-pola dari materi yang sudah dipelajari sebelumnya dengan baik, yang merupakan dampak dari bahan ajar (LKS) yang digunakan siswa pada saat implementasi desain didaktis. Sejalan dengan penelitian. Guru mengelola situasi didaktik yang menciptakan dan memanfaatkan situasi matematika di mana pembelajaran dilakukan dan pengetahuan matematika siswa dikembangkan (Brousseau et al., 2020)

Berdasarkan sudut pandang lain, ketika siswa melakukan proses representasi dapat memacu guru terkait kemampuan mengajarnya bisa lebih baik dan meningkat.

\section{KESIMPULAN DAN SARAN}

\begin{tabular}{lcr}
\multicolumn{1}{c}{ Setelah } & implementasi & desain \\
didaktis & matematika & yang \\
dikembangkan & berdasarkan & hasil
\end{tabular} analisis pendahuluan yang dilakukan untuk melihat learning obstacle dan melakukan analisis teoritis, kemampuan representasi matematika yang terdiri dari proses representasi visual, proses pembuatan persamaan dan proses pembuatan kata-kata tertulis terlaksana dan siswa melakukannya dengan baik. Berdasarkan hasil evaluasi, pada proses siswa membuat model atau ekspresi matematis, hampir seluruh siswa sudah melakukannya dengan benar dilihat dari hasil jawaban tes akhir siswa menjawab dengan benar, sedangkan pada proses siswa membuat kata-kata tertulis dan representasi visual, sebagian siswa sudah benar akan tetapi masih terdapat beberapa siswa yang masih melakukan kesalahan dalam membuat gambar serta membuat argumen atau kesimpulan untuk memperjelas permasalahan yang diberikan.
Saran berdasarkan hasil penelitian, yaitu hasil pengembangan desain didaktis pada materi trigonometri dapat diterapkan di SMA untuk meminimalisir hambatan yang terjadi pada siswa serta kebutuhan siswa tersebut, penelitian pengembangan desain didaktis sebaiknya dilakukan dengan materi yang berbeda disesuaikan dengan permasalahan dan hambatan yang terjadi pada siswa, untuk melihat apakah desain yang telah dirancang cocok untuk semua siswa, maka sebaiknya implementasi desain dilakukan pada sekolah-sekolah dengan kluster dan jenjang yang berbeda.

\section{DAFTAR PUSTAKA}

Amiripour, P., Amir-Mofidi, S., \& Shahvarani, A. (2012). Scaffolding as an Effective Method for Mathematical Learning. Indian Journal of Science and Technology, 5(9), 3328-3331.

Arnidha, Y. (2016). Peningkatan Kemampuan Representasi Matematis Melalui Model Pembelajaran Kooperatif. Jurnal E-DuMath, 2(1), 128-137.

Brousseau, G., Sarrazy, B., \& Novotná, J. (2020). Didactic Contract in Mathematics Education. In Encyclopedia of Mathematics Education (pp. 197-202).

Cadez, T. H. (2018). Exploring Processes in Constructing Mathematical Concepts and Reasoning Through Linking Representations. Center for Educational Policy Studies Journal, 8(2), 5-8.

Dahlan, J. A., \& Juandi, D. (2011). Analisis Representasi Matematik Siswa Sekolah Dasar Dalam Penyelesaian Masalah Matematika Kontekstual. Jurnal 
DOI: https://doi.org/10.24127/ajpm.v10i4.3971

Pengajaran Matematika Dan Ilmu Pengetahuan Alam, 16(1), 128137.

Devesh, S., \& Nasseri, D. A. L. (2014). Effectiveness of Mathematics Module in Foundation Programme in Majan College. International Journal of Emerging Engineering Research and Technology, 2(1), 1-7.

Goldin, G. A. (2002). Representation in Mathematics Learning and Problem Solving. In Handbook of International Research in Mathematics Education (IRME) (p. 209). Lawrence Erlbaum Associates.

Khasanah, U. (2015). Kesulitan Menyelesaikan Soal Cerita Matematika pada Siswa SMP. Skripsi Universitas Muhammadiyah: Malang.

Kholiqowati, H., Sugiarto, I., \& Hidayah. (2016). Analisis Kemampuan Representasi Matematis Ditinjau dari Karakteristik Cara Berpikir Peserta Didik dalam Pembelajaran dengan Pendekatan Saintifik. Unnes Journal of Mathematics Education, 5(3), 234-242.

Komala, E., Suryadi, D., \& Dasari, D. (2020). Learning Obstacle Related to the Ability of High School Student Representation to the Trigonometry Concept. In Proceeding books: The 2nd International Conference and Innovation Exhibition Global Education (ICEGE) (pp. 43-49).

Mulyana, E., Turmudi, \& Juandi, D. (2014). Model Pengembangan Desain Didaktis Subject Specific Pedagogy Bidang Matematika Melalui Program Pendidikan Profesi Guru. Jurnal Pengajaran MIPA, 19(2), 141-149.
NCTM. (2000). Principles and Standards for School Mathematics. NCTM.

Putra, B. (2018). Peningkatan Kemampuan Representasi dan Abstraksi Matematis serta SelfAwareness SIswa SMP Melalui Cognitive Apprenticeship Instruction. Universitas Pendidikan Indonesia.

Rezeki, S. (2017). Meningkatkan Kemampuan Representasi Matematika Siswa Melalui Penerapan Model Pembelajaran Novick. SAP (Susunan Artikel Pendidikan), 1(3), 281-291.

Wilujeng, H. (2019). Peningkatan Kemampuan Berpikir Aljabar dan Multi Representasi Matematis Serta Pencapaian SelfDetermination Siswa SMP Melalui MERRIL'S First Principles of Instruction. Universitas Pendidikan Indonesia.

Yunarti, T. (2014). Desain Didaktis Teori Peluang SMA. Jurnal Pendidikan MIPA, 15(1), 15-20.

Yusnita, I., Maskur, R., \& Suherman, S. (2016). Modifikasi Model Pembelajaran Gerlach dan Ely Melalui Integrasi Nilai-Nilai Keislaman Sebagai Upaya Meningkatkan Kemampuan Representasi Matematis. AlJabar: Jurnal Pendidikan Matematika, 7(1), 29-38. 